\title{
Board Structure and Likelihood of Financial Distress: An Emerging Asian Market Perspective
}

\author{
Shahab UD-DIN ${ }^{1}$, Muhammad Yar KHAN ${ }^{2}$, Anam JAVEED ${ }^{3}$, Ha PHAM ${ }^{4}$ \\ Received: August 01, 2020 Revised: September 20, 2020 Accepted: October 05, 2020
}

\begin{abstract}
This study examines the relationship between the attributes of board structure and the likelihood of financial distress for the non-financial sector of an emerging market characterized by concentrated ownership and family-controlled business. The present study utilized panel logistic regression to estimate the relationship between board structure attributes and the likelihood of financial distress. We used Altman Z-Score as a proxy for firm financial distress, as this tool measures the financial distress inversely. The study finds a significant relationship between board size and the likelihood of financial distress. The results show that a one-unit increase in board size would decrease the probability of financial distress by $3.4 \%$. Further, we observe that a greater level of board independence is associated with a lower likelihood of financial distress. A one-unit increase in board independence would decrease the probability of financial distress by $20.4 \%$. We also find a significant positive impact of leverage on the likelihood of financial distress. The present study contributes to the body of literature on board structure attributes and likelihood of financial distress in emerging markets, like Pakistan. Furthermore, the findings would be beneficial for corporate policymakers and investors in formulating corporate financial strategy and predicting business failure.
\end{abstract}

Keywords: Corporate Governance; Board Structure; Financial Distress; Emerging Market; Altman Z-Score

JEL Classification Code: G33, G34, G23, O16

\section{Introduction}

The prominence of corporate governance received attention back early in the 1930 s since the introduction of the separation theory of ownership structure and control (Berle \& Means, 1932). However, from the last two decades, there is a continuing debate on the importance of corporate governance, which sets procedures for companies to operate the business in an effective manner. The corporate

${ }^{1}$ First Author. Assistant Professor, Business Management Sciences, Karakoram International University, Gilgit-Baltistan, Ghizer Campus, Pakistan. Email: shahabuddin@kiu.edu.pk

${ }^{2}$ Assistant Professor, Department of Management Sciences, COMSATS University Islamabad, Wah Campus, Pakistan.

Email: muhammadyar@ciitwah.edu.pk

${ }^{3}$ Assistant Professor, Management Sciences, University of Wah, Wah Cantt, Pakistan. Email: dr.anam.javeed@uow.edu.pk

${ }^{4}$ Corresponding Author. Dean, Faculty of Banking and Finance, Ho Chi Minh City Open University, Vietnam [Postal Address: 97 Vo Van Tan St, Dist 3, Ho Chi Minh City, 70000, Vietnam] Email: ha.p@ou.edu.vn

(c) Copyright: The Author(s)

This is an Open Access article distributed under the terms of the Creative Commons Attribution Non-Commercial License (https://creativecommons.org/licenses/by-nc/4.0/) which permits unrestricted non-commercial use, distribution, and reproduction in any medium, provided the original work is properly cited. governance mechanisms include ownership structure, board structure, board meetings, protection of minority shareholder's rights, and financial reporting. Among the corporate governance mechanisms, board structure is the core element and influences corporate decisions across the globe. There are considerable legislation and requirements for the board structure in both developed and emerging markets. For instance, Aguilera and Cuervo-Cazurra (2009) and Crespí-Cladera and Pascual-Fuster (2014) contended that the Code of corporate governance (henceforth CCG) across the world, particularly in developed counties, made recommendations on the board structure, specifically about the presence of independent directors.

Similarly, Cadbury (1992) presents board structure as the heart of the corporate governance system, through which companies are directed and governed. Further, the role of board is critical in developing countries, where business has concentrated ownership, controlled by business groups and family members. Pakistan has an emerging financial market and gradually improves its governance standards, and in line with international corporate governance standards. Security \& Exchange Commission of Pakistan (SECP) has made it mandatory for listed companies to adopt 
Clause III of CCG 2016 and CCG 2013 regarding board composition $^{1}$. Similarly, corporate governance reforms in developed countries like the US and UK have focused on the board structure, by appointing independent directors and making the board independent from the CEO. Furthermore, corporate governance committees like the Cadbury (1992), Greenbury (1995), Committee (1998), and Higgs (2003) have recommended the appointment of independent directors on the board and discourage the dual role of CEO.

In Pakistan, business is predominantly of a family origin and in large business groups, corporate governance mechanisms rely on the internal mechanism rather than external ones for enhancing the firm's financial performance and reducing the likelihood of financial distress. In this context, corporate board structure such as board size, board independence, and CEO duality are important elements of the internal corporate governance mechanisms in Pakistan, an emerging market. Elloumi and Gueyie (2001) define financial distress as the inability of a firm to meet its financial obligations in the long run due to business failure. Furthermore, if the earnings per share of a firm have been negative in the long run, then it is said to be financially distressed. Tahir et al. (2020) document the evidence that corporate governance practices improve the firm's financial performance and report a significant positive association between liquidity and firm financial performance. Jensen (1993) suggests that effective internal control can reduce the likelihood of business failure. Further, he argued that board structure is the primary tool of internal control and internal corporate governance mechanism. He also added that poor financial performing firms had limited independent directors on their boards.

Fama and Jensen (1983) argued that the board of directors acts as a representative of shareholders, and its primary responsibility is to reduce agency costs and enhance financial performance. In the regulatory environment of Pakistan, the board of directors of the listed firms has fiduciary responsibilities to provide active supervision and do the strategic decision-making. The board is an integral part of the corporate governance mechanism Pakistani corporate environment, which is categorized by high concentrated ownership, dominant shareholders, large business groups and insider control. In addition, controls of the firms lie in the hands of a group of few people. Pakistan is an emerging market and facing agency problem known as principal-principal (conflict among large and minority shareholders). In this scenario, the role of the composition of the board of directors is critical to normalize the principal-principal agency problem and protecting the wealth of minority shareholders against the exploitation of large shareholders and, subsequently, from the business failure.
Further, Rahman and Saima (2018) suggest that large board is the significant explanatory variable in improving firm performance. This is because the role of the board of directors is active monitoring of the managerial behavior and aligning the interest of minority and majority shareholders (Bethel \& Liebeskind, 1993; Manzaneque et al., 2016; Pound, 1992). Furthermore, suitable corporate governance mechanisms improve the firm financial performance and protect against the risk of financial distress (Black et al., 2006; Hodgson et al., 2011; Nahar Abdullah, 2006). However, many studies have found that corporate governance practices play a key role in predicting the likelihood of business failure (Brédart, 2014; Chen, 2014; Lee \& Yeh, 2004; Lin et al., 2010; Manzaneque et al., 2016; Manzaneque et al., 2016).

According to the above-cited studies, this paper analyzes the impact of board structure on the likelihood of financial distress in a context of an emerging market with unique institutional background, concentrated ownership, and family-owned business groups and corporate governance practices in line with international standards. The results of this study extend the literature on corporate governance practices, specifically board structure and the likelihood of financial distress, and also open new avenues for further research in emerging markets.

The rest of the paper is organized as follows: Section 2 discusses the literature review and develops the hypotheses. Section 3 contains the research design, while Section 4 describes the empirical results. Section 5 provides conclusion and policy implications.

\section{Literature Review and Hypotheses}

Corporate governance studies have scant evidence on the relationship between corporate governance practices and the likelihood of financial distress and provide inconclusive results. Previous studies show that corporate governance attributes, such as ownership structure and board structure, have an impact on the likelihood of financial distress (such as (Donker et al., 2009; Lajili \& Zéghal, 2010; Mangena \& Chamisa, 2008; Manzaneque et al., 2016; Manzaneque et al., 2016; Miglani et al., 2015; Wang \& Deng, 2006).

Jensen (1993) has suggested that limited board members effectively managed corporations. A large number of board members is a burden on the corporate resources, while usually disagreement among board members slow down the decision-making process. The disagreement among large board members benefits the management, and they start to secure their self-interest. Chaganti et al. (1985) also proposed that the small board plays a significant role and has effective control over the management than the large board size. Large boards have a lack of coordination and lose control of the management. The managers of the entity take this advantage and pursue their self-interests. Majeed 
et al. (2020) find a significant positive association between board size and financial performance measured by ROA, while the insignificant negative relationship between ROE in Pakistani listed banks.

Additionally, they report significant positive relationship between board size, ROA and ROE in Chinese listed banks. Lipton and Lorsch (1992) have observed that small boards are more effective than large boards. They argue that large board size has a lack of coordination, which precludes strategic decision-making. An inverse relationship is reported between firm financial performance and board size (Yermack, 1996). Business failure is the result of a dysfunctional corporate internal system (Jensen, 1993). Hermalin and Weisbach (1988) contended that poor-performing firms should increase the number of independent directors on the board. Based on the above-cited literature, the following hypothesis is to be tested:

$\boldsymbol{H}_{1}$ : There is a negative relationship between board size and the likelihood of firm financial distress.

Furthermore, financial distress firms have a high proportion of insider directors (Baysinger \& Butler, 1985; Salancik \& Pfeffer, 1980). Khan et al. (2016) suggest that corporate governance practices such as board independence lead towards the initiation of the firm enterprise risk management program (ERM) in order to manage the organizational risk. Fuzi et al. (2016) argued that the existence of independent directors on board should be monitored in order to bring positive shareholder values. Liu et al. (2015) examine the relation between board independence and firm performance in China and report that board independence is positively related to firm operating performance in China. Further, they argued that the degree of board independence is positively and significantly related to firm performance, especially in government-controlled firms and in firms with lower information acquisition and monitoring costs. Elloumi and Gueyie (2001), Daily et al. (2003) and Hambrick and D'Aveni (1992) report that firms with a large proportion of independent directors show a smaller probability to file for bankruptcy. Moreover, Fich and Slezak (2008), studies linking board configuration to financial distress show that smaller boards with more independent or outsides directors are more effective at avoiding bankruptcy. Based on the above empirical studies, following hypothesis is to be tested:

$\boldsymbol{H}_{2}$ : There is a negative relationship between board independence and the likelihood of firm financial distress.

CEO-dominated firms have a high probability of business failure due to the dual role and self-interest behavior (Hambrick \& D’Aveni, 1992). Mallette and Fowler (1992) claimed that separation of the positions of CEO and board chair leads to a more powerful board of directors, which reflects improved ability to oversee management. Further, He et al. (2007) claimed that the dual position of the board chairman hijacks the board's monitoring role, which leads to more instances of earnings management occurring in firms rather than profit maximization. Daily and Dalton (1994) argued that the separated independent position of board chair reduces the opportunistic behavior of the CEO of selfserving on the cost of owners. In a similar vein Chen et al. (2005) argued that managerial entrenchment in the form of CEO-chair duality makes the CEO more powerful within the firm and less likely to be replaced or challenged by the board of directors. Tahir et al. (2020) find a significant positive association between board attributes (such as board size, board members average age, board tenure) and dividend policy.

Miglani et al. (2015) support the argument that greater levels of block-holder and director ownership, and the existence of a separate audit committee are associated with lower financial distress likelihood. Sheikh et al. (2019) find a significant positive association between CEO compensation and the future operating performance of the firms listed at the Pakistan Stock Exchange. Additionally, they report an insignificant association between excessive CEO compensation and future operating performance. Nakano and Nguyen (2012) find a significant negative relationship between board structure, probability of business failure and volatility. The presence of a high percentage of outside directors in the audit committee and board remuneration committee will reduce the probability of corporate failure (Lakshan \& Wijekoon, 2012). Manzaneque, Merino, et al. (2016) and Manzaneque, Priego, et al. (2016) report insignificant role of institutional shareholders on likelihood of business failure in a concentrated ownership environment. Further, they find a significant negative impact of board size on financial distress likelihood. They also argued the insignificant effect of CEO duality on the likelihood of business failure. Based on the above empirical studies, the following hypothesis is to be tested:

$\boldsymbol{H}_{3}$ : There is a positive relationship between CEO duality and the likelihood of firm financial distress.

\section{Research Design and Methodology}

\subsection{Data and Sample Selection}

To examine the effect of board structure attribute on the likelihood of firm financial distress in an emerging market, we focus our attention on non-financial listed firms of Pakistan. The non-financial sector of the country is sound and major contributor to the economy ${ }^{2}$. This study uses a 
sample of 146 firms listed on the Pakistan Stock Exchange (PSX) over a period of 15 years, from 2005 to 2019. Initially, we have started with 200 firms listed in different sectors. However, due to the unavailability of published reports and inconsistency of data, 54 firms were excluded from the sample. The selected companies consist of both large and small firms on the bases of market capitalization, while the board structure variables are extracted and calculated from the published Annual Reports of the sample firms. Furthermore, financial data is obtained from the Balance Sheet Analysis of Joint Stock Companies published by the State Bank of Pakistan (SBP).

\subsection{Measurement of Variables}

\section{- Board Structure Attributes}

The board structure is the most crucial element of the corporate governance structure. In this study, we use three proxies to measure the board structure: board size (BS), board independence (BIND), and CEO duality (CEODU).

\section{- Financial Distress}

A dummy variable " 1 " and " 0 " is created to identify financial distress and financially sound firms. $F D_{i t}$ represents the likelihood of financial distress of the company; the sample companies are classified into "financially sound" and "financial distress" on the basis of Altman Z-score (Altman, 1968) value. Altman Z-score ${ }^{3}$ value provides a threshold to predict a firm's financial health and distance to financial distress. Financiallysound firms have Z-score value above of 1.81 and if the companies have Z-score value less than 1.81 are classified as financially-distressed companies $F D_{i t}$ takes the value of "1" if the value of Z-score is less than 1.81 and classified as financially distressed, otherwise " 0 " for financially sound firms.

\section{- Control Variables}

Considering previous literature on corporate governance studies, we selected a firm's size, net profit margin, payout ratio, leverage and sales growth as control variables to examine the relationship between board structure and the likelihood of financial distress. Table 1 provides definitions, abbreviations, expected signs and data sources.

Table 1: Classification, Abbreviation, Definition, expected sign and Date sources of the Variables

\begin{tabular}{|c|c|c|c|c|}
\hline Variables & Abbreviation & $\begin{array}{l}\text { Expected } \\
\text { Signs }\end{array}$ & Definition & Sources \\
\hline $\begin{array}{l}\text { Financial } \\
\text { Distress }\end{array}$ & $F D_{i t}$ & $-/+$ & $\begin{array}{l}\text { Dummy variable takes value } 1 \text { when the company } \\
\text { is financial distress and } 0 \text {, otherwise. We consider } \\
\text { a company as "distressed" on the bases of } \\
\text { Altman's Z-score value. } \\
\begin{aligned} \text { ZScore }=0.012 X_{1}+0.014 X_{2}+0.033 X_{3}+0.006 X_{4} \\
\quad+0.999 X_{5}\end{aligned} \\
\begin{array}{l}\text { Where } X_{1}=\text { networking capital /total assets, } X_{2} \\
=\text { retained earnings /total assets, } X_{3}=\text { Earnings } \\
\text { before interests and taxes }\left(\text { EBIT)/total assets, } X_{4}\right. \\
=\text { market value of equity and preferred stock/book } \\
\text { value of debt, and } X_{5}=\text { sales revenue/total assets. }\end{array}\end{array}$ & Calculated by Authors \\
\hline Board Size & $B S_{i t}$ & $+/-$ & Natural log of total No. of Board members & $\begin{array}{l}\text { Annual Reports of the } \\
\text { companies }\end{array}$ \\
\hline $\begin{array}{l}\text { Board } \\
\text { Independence }\end{array}$ & $B I N D_{i t}$ & - & $\begin{array}{l}\text { Non-Executive Directors/ Total No. of Directors in } \\
\text { Board) being in line with (i.e., Kee et al., 2003; Lin } \\
\text { Chen, 2008) }\end{array}$ & $\begin{array}{l}\text { Annual Reports of the } \\
\text { companies }\end{array}$ \\
\hline CEO Duality & $C E O D U_{i t}$ & + & $\begin{array}{l}\text { A dummy variable that equals to } 1 \text { if the firm has } \\
\text { CEO as Chairman of the board. Otherwise, it is } 0 .\end{array}$ & $\begin{array}{l}\text { Annual Reports of the } \\
\text { companies }\end{array}$ \\
\hline Profit Margin & $P M_{i t}$ & - & Net income over Net sales & Balance Sheet Analysis \\
\hline Firm Size & $S I Z E_{i t}$ & - & Natural log of Market capitalization & Balance Sheet Analysis \\
\hline Payout ratio & PRatio $_{\text {it }}$ & + & $\begin{array}{l}\text { Cash dividend to common shareholders/ Net } \\
\text { Income }\end{array}$ & Calculated by Authors \\
\hline Leverage & $L e v_{i t}$ & + & $\begin{array}{l}\text { The debt to total assets ratio is an indicator of } \\
\text { financial leverage. } \\
\text { Debt to Asset= Total Debt/Total Asset }\end{array}$ & $\begin{array}{l}\text { Balance Sheet } \\
\text { Analysis }\end{array}$ \\
\hline Sales Growth & Grwth $_{i t}$ & - & $\begin{array}{l}\text { (Current year Sales minus Previous year Sales)/ } \\
\text { Previous year Sales }\end{array}$ & Calculated by authors \\
\hline
\end{tabular}




\subsection{Methodology and Model Specifications}

Panel logistic regression is used to estimate the relationship between board structure attributes and financial distress likelihood. Following the methodology of Manzaneque, Merino, et al. (2016) and Mangena and Chamisa (2008), panel logistic is applied to overcome the limitations of the ordinary least squares (OLS) parameters when the dependent variable appears as a dummy variable. We specify the following econometric model:

$$
\begin{aligned}
\operatorname{Logit}\left(F D_{i t}\right)= & \alpha_{0}+\alpha_{1} B S_{i t}+\alpha_{2} \text { BIND }_{i t}+\alpha_{3} C E O D U_{i t} \\
& +\alpha_{4} \text { Size }_{i t}+\alpha_{5} P M_{i t}+\alpha_{6} P R_{i t}+\alpha_{7} L E V_{i t}+\alpha_{8} \\
& G R W_{i t}+d_{i t}+\eta_{i t}+\varepsilon_{i t}
\end{aligned}
$$

Where $F D_{i t}$ A dummy variable " 1 " and " 0 " is created to identify financial distress and financially sound firms. $F D_{i t}$ takes the value of " 1 " if the value of Z-score is less than 1.81 and classified as financially distressed, otherwise " 0 " for financially sound firms. $d_{t}=$ Time effect; $\eta_{i}=$ Individual effect; $\varepsilon_{i t}=$ Random disturbance.

\section{Data Analysis, Results and Discussion}

\subsection{Descriptive Statistics}

The descriptive statistics presented in Table 2 provide information about the sample characteristics, such as mean value, median, standard deviation, maximum value, and minimum value. Table 3 presents summary statistics of total borrowing, total assets, equity, dividend payments, sales, market capitalization, and total profit of the sample companies. The selected sample consists of both large and small firms on the bases of market capitalization. The mean value of the sales is Rs.13,954.99 million, with a median of Rs.2,926.85million. The mean value varies between Rs.13.37 million to Rs.820,530.4 million.
The average market capitalization is Rs.10,788 million. The large company, which has maximum market capitalization, is Rs.828,401.80, while the minimum value of market capitalization is Rs.0.000 million, which provides evidence of small and financial distress companies. The standard deviation is Rs.49,010.21. This high value of standard deviation could be due to large size companies in the sample and indicates that data is not consistent.

Similarly, the average value of the total assets is Rs.8,971.00 million, while the standard deviation is Rs.16,049.60 million. The high value of standard deviation than the mean value of total assets shows the variation in total assets, which could be due to large companies in the sample. The average dividend paid by the sample firms is Rs.232 million and varies from Rs.0.00 million to Rs.8,279.11 million. The minimum value of Rs. 0.00 million shows that some companies in the sample are not paying dividends to shareholders. The average debt, shareholder's equity, and net profit are Rs.5,028 million, Rs.232 million and Rs.1,040 million, respectively.

The mean and median of board independence is 0.55 and 0.57 , respectively, and suggest that major listed firms at PSX have 55 percent board independence practices, which is in line with the Code of corporate governance issued by the Security Exchange Commission of Pakistan (SECP). Furthermore, corporate governance rule 2013 issued by SECP has clearly said about board structure that "Board shall have forty percent of its total members as independent directors within the first two years of this notification, which shall be raised to a majority of independent directors in the next two years, and the majority shall be maintained subsequently. The public-sector companies should disclose the number of Non-executives, Executive and Independent Directors in the annual report" (p.621-622). The maximum and minimum board independence are 100 percent and 0 percent, respectively. The highest proportion is belonging to the petroleum refinery sector. Many of them are stateowned corporations and major directors appointed by the government of Pakistan.

Table 2: Descriptive Statistics of Board Structure, Z-score and Firm's Financial Variables (PKR Millions)

\begin{tabular}{|l|c|c|c|c|c|c|c|c|}
\hline Variables & Mean & Median & Max & Min & Std. Dev. & Skewness & Kurtosis & obs \\
\hline Debt & 5028 & 1530.98 & 96144.9 & 10.26 & 9502.1 & 4.24 & 26.8 & 2190 \\
\hline Dividend & 232 & 10.4 & 8279.11 & 0.00 & 720.44 & 5.6 & 41.53 & 2190 \\
\hline Equity & 3942 & 1057.15 & 98225.7 & -3672.9 & 8996.8 & 5.81 & 47.71 & 2190 \\
\hline Sales & 13955 & 2926.85 & 820530.4 & 13.3727 & 46571.8 & 10.41 & 146.2 & 2190 \\
\hline Total Assets & 8971 & 2994.61 & 127004.5 & 23.18 & 16049.6 & 3.59 & 18.46 & 2190 \\
\hline Market Capitalization & 10788 & 912.1 & 828401.8 & 0.00 & 49010.21 & 10.61 & 138.16 & 2190 \\
\hline Board size & 8.13 & 7 & 17 & 7 & 1.62 & 1.77 & 6.73 & 2190 \\
\hline Board Independence & 0.557 & 0.571 & 1 & 0 & 0.22 & -0.097 & 2.668 & 2190 \\
\hline Z-Score & 2.74 & 2.01 & 74.63 & -8.87 & 4.27 & 9.15 & 25.20 & 2190 \\
\hline
\end{tabular}


A zero proportion of board independence exists in the textile sector. The textile sector is the most important manufacturing sector in Pakistan. Most of the firms in this sector are a family-owned business; the business is managed by the family members and large business groups. Similarly, the average board size of public listed companies in our study sample is eight directors and varies between seven to seventeen board members. The summary statics of the board size series presents that listed companies have fulfilled the requirement of the Code of corporate governance and the company's ordinance 1984. Both the code and company ordinance 1984 has a requirement of, at least, seven directors in listed companies and shall be elected in annual general meeting. The standard deviation of series is within the mean value, supporting low variation in the data series. Similarly, the mean and median value of Z-score (used as a proxy to measure the probability of financial distress) is 2.74 and 2.01 , respectively. The average value of the $\mathrm{Z}$-score is higher than 1.81, which shows that major companies in our sample are in a safe zone and at a distance from financial distress. Similarly, the minimum value of the Z-score is -8.87 , which indicates the presence of financially distressed firms in the sample firms.

\subsection{Correlation Analysis}

Correlation analysis is used to examine the multicollinearity among the independent variables. Multicollinearity is a serious problem of the data, which needs to be addressed before using regression analysis. Nanka-Bruce (2009) argued that "collinearity among the model's independent variables inflates standard errors and result in overfitting, potentially overestimating the effects of some collinear variables and underestimating the effects of other". The correlation coefficient between the two independent variables must be less the 80 percent.
Table 3 reports the correlation coefficient between board structures, financial distress, and control variables. Board size and CEO duality are negatively correlated with Z-score (financial distress index). The correlation coefficient between board size and CEODU is -0.026 and -0.282 , respectively. We observed a positive association between board independence and Z-score, which indicates that board independence in listed companies improves a firm's efficiency and saves firms from financial distress.

We also observed a significant positive correlation between CEO duality and the leverage of the firm. Further, a significant negative association between CEO duality and firm size is observed. CEO duality is negatively correlated with profit margin and payout ratio. Similarly, board size has a significant negative association with leverage but a significant positive association with firm size.

\subsection{Empirical Results}

Table 4 presents the results of the panel logistic regression, which tests the relationship between board structure and financial distress. Logistic regression exhibits a significant negative relationship between board size and the likelihood of financial distress. Our finding is consistent with Manzaneque, Priego, et al. (2016); they reported a negative and significant impact of board size on the likelihood of a firm's financial distress in Spanish companies. Our result implies that a larger board size minimized the overlapping role, which may improve the efficiency of board members. Similarly, our finding is in line with resource dependency theory which hypothesized that companies with large board size have the ability to control the opportunistic behavior of managers and to access the resources and information, which can reduce the likelihood of financial distress (Pearce \& Zahra, 1992; Pfeffer, 1972).

Table 3: Correlation Matrix

\begin{tabular}{|l|c|c|c|c|c|c|c|c|}
\hline Variables & Leverage & Growth & $\begin{array}{c}\text { Firm's } \\
\text { Size }\end{array}$ & $\begin{array}{c}\text { Payout } \\
\text { Ratio }\end{array}$ & $\begin{array}{c}\text { Profit } \\
\text { Margin }\end{array}$ & $\begin{array}{c}\text { Board } \\
\text { Size }\end{array}$ & $\begin{array}{c}\text { Board } \\
\text { Independence }\end{array}$ & $\begin{array}{c}\text { CEO } \\
\text { Duality }\end{array}$ \\
\hline Leverage & 1 & & & & & & & \\
\hline Growth & -.016 & 1 & & & & & & \\
\hline Firm's Size & $-.268^{* *}$ & $.059^{*}$ & 1 & & & & & \\
\hline Payout Ratio & $-.055^{*}$ & .006 & $.105^{* *}$ & 1 & & & & \\
\hline Profit Margin & $-.108^{* *}$ & $.059^{*}$ & $.059^{*}$ & .012 & 1 & & & \\
\hline Board Size & $-.053^{*}$ & -.001 & $.323^{* *}$ & .029 & .028 & 1 & & \\
\hline Board Independence & -.020 & .026 & .039 & -.021 & -.009 & .032 & 1 & \\
\hline CEO Duality & $.110^{* *}$ & .019 & $-.146^{* *}$ & -.024 & -.009 & $-.100^{* *}$ & -.042 & 1 \\
\hline
\end{tabular}

"Correlation is significant at the 0.01 level (2-tailed).

"Correlation is significant at the 0.05 level (2-tailed). 
Shahab UD-DIN, Muhammad Yar KHAN, Anam JAVEED, Ha PHAM /

Table 4: Board Structure attributes and Likelihood of Financial Distress

\begin{tabular}{|c|c|c|c|}
\hline Variables & Coefficients & Odds Ratios & Marginal Effects \\
\hline Constant & $\begin{array}{l}-1.192^{*} \\
(-1.94)\end{array}$ & $\begin{array}{l}0.303^{*} \\
(-1.94)\end{array}$ & - \\
\hline$B S_{i t}$ & $\begin{array}{c}-0.140^{* * *} \\
(-3.75)\end{array}$ & $\begin{array}{l}0.868^{*+* t} \\
(3.75)\end{array}$ & $\begin{array}{c}-0.034^{+* *+} \\
(-3.74)\end{array}$ \\
\hline$B I N D_{i t}$ & $\begin{array}{c}-0.831^{*+*} \\
(-2.76) \\
\end{array}$ & $\begin{array}{l}-2.29 \\
(-2.76) \\
\end{array}$ & $\begin{array}{c}-0.204^{+* *+} \\
(-2.76) \\
\end{array}$ \\
\hline CEODU $_{i t}$ & $\begin{array}{l}0.193 \\
(0.43) \\
\end{array}$ & $\begin{array}{c}1.21 \\
(0.43) \\
\end{array}$ & $\begin{array}{l}0.047 \\
(0.43) \\
\end{array}$ \\
\hline Size $_{i t}$ & $\begin{array}{c}-0.126 \\
(-4.22) \\
\end{array}$ & $\begin{array}{l}0.881^{m * *} \\
(-4.22)\end{array}$ & $\begin{array}{c}-0.031^{* * *} \\
(-4.22)\end{array}$ \\
\hline $\operatorname{Lev}_{i t}$ & $\begin{array}{l}3.923^{* * *} \\
(12.42)\end{array}$ & $\begin{array}{l}50.56^{* * *} \\
(12.42)\end{array}$ & $\begin{array}{l}0.963^{* * *} \\
(12.39)\end{array}$ \\
\hline Growth $_{i t}$ & $\begin{array}{l}-0.195 \\
(-1.29) \\
\end{array}$ & $\begin{array}{c}0.822 \\
(-1.29) \\
\end{array}$ & $\begin{array}{l}-0.047 \\
(-1.29) \\
\end{array}$ \\
\hline$P M_{i t}$ & $\begin{array}{l}-0.107 \\
(-0.84) \\
\end{array}$ & $\begin{array}{c}0.898 \\
(-0.84) \\
\end{array}$ & $\begin{array}{l}-0.026 \\
(-0.84) \\
\end{array}$ \\
\hline Pratio $_{i t}$ & $\begin{array}{l}-0.035 \\
(-0.66) \\
\end{array}$ & $\begin{array}{c}0.964 \\
(-0.66) \\
\end{array}$ & $\begin{array}{l}-0.008 \\
(-0.66) \\
\end{array}$ \\
\hline McFa R - square & 0.1604 & - & - \\
\hline LR statistic & 32.10 & - & - \\
\hline Prob (LR statistic) & 0.0000 & - & - \\
\hline Observations & 2190 & 2190 & 2190 \\
\hline
\end{tabular}

Note: Financial Distress is a binary variable in Logit is estimation technique, " 1 " for financially distressed and " 0 " for the non-financial distressed firm. The ${ }^{* * *}$ denotes $1 \%,{ }^{* *}$ denotes $5 \%$ and ${ }^{*}$ denotes $10 \%$ level of significance; t-values are presented below coefficients in parenthesis.

We find a significant negative relationship between board independence and financial distress likelihood, which is in line with the expected sign. This result confirms earlier findings by Wang and Deng (2006), Mangena and Chamisa (2008), Hui and Jing-Jing (2008), Manzaneque, Priego, et al. (2016), Manzaneque, Merino, et al. (2016). The result implies that firms having more independent directors on the board have a low probability of financial distress. The Independent directors affectively control and monitor management decisions, especially those affecting the companies outside shareholders.

In the presence of larger board size and higher board independence, the role of the dual CEO becomes passive. The logit analysis confirms this view and reports an insignificant positive association between CEO duality the likelihood of firm financial distress. Our finding is consistent with Hui and Jing-Jing (2008), and Manzaneque, Merino, et al. (2016) conclude an insignificant relation between positive CEO duality and the likelihood of a firm's financial distress.

Among the control variables, a firm's size has a negative and significant association with the likelihood of financial distress. The negative coefficient of firm size implies that large companies have a low risk of default due to their experiences and operational efficiency. Similarly, leverage is found to be positive and significant, which suggests that debt financing can enhance the probability of financial distress. This result is not surprising in the case of Pakistan because, in Pakistan, financial institutions and other loan-providing agencies are not capable of monitoring the usage of loans at the firm level. Furthermore, the payout ratio, profit margin, and sales growth are negatively correlated with the probability of financial distress.

It is worth mentioning here that we cannot directly interpret the parameter estimates based on the PLR model. To obtain interpretable parameter estimates, we need to calculate the odds ratio and marginal effect of each coefficient. Table 4 (Colum $3 \& 4$ ) presents the odd ratios and effects and marginal effects of the coefficients.

With reference to marginal effect, a one-unit increase in board size is associated with a $3.4 \%$ decrease in the probability of financial distress. This would suggest that the number of board members plays an important role in 
monitoring managers' activities to improve firm financial performance. Moreover, the resource dependency theory argues that board members offer various advantages like access to resources and information to achieve firm objectives. Similarly, a one-unit increase in board independence would decrease the probability of financial distress by $20.4 \%$, suggesting that board independence has a maximum economic impact on financial distress likelihood among the board structure attributes. The reason could be that in a concentrated ownership environment, the independent directors play an important role in improving the financial conditions of the business through active monitoring of the board decisions of the board. The independent directors also defend the minority shareholders from the exploitation of majority shareholders. Thus, our finding is consistent with the prediction of agency theory and active monitoring arguments. We observed a positive association between CEO duality on financial distress likelihood, although the result is statistically insignificant.

With respect to the control variables, leverage has a significant positive association with the likelihood of financial distress, in line with the findings consistent with the findings of Chen and Church (1992) and Flagg et al. (1993). A one-unit increase in leverage is associated with a $96 \%$ increase in the probability of business failure, which suggests that debt financing can enhance the probability of financial distress. This result is not surprising in the case of Pakistan because, in Pakistan, financial institutions and other loan-providing agencies are not capable of monitoring the usage of loans at the firm level. Furthermore, a unite increase in the firm size and growth is associated with a reduction in financial distress probability by $3.1 \%$ and $4.7 \%$, respectively. This confirms that large and growing firms are less likely to experience financial distress due to operational experience and access to external resources.

\section{Conclusion and Policy Implications}

The main objective of this paper is to examine the relationship between board structure attributes and the likelihood of financial distress of 146 manufacturing firms listed on the Pakistan Stock Exchange (PSX) over a period of 15 years from 2005 to 2019.

We observed a significant negative relationship between board independence and the likelihood of firm financial distress, which suggests that companies with more independent directors on board have a low probability of financial distress because independent directors affectively control and monitor management decisions, especially those affecting the company's minority shareholders. The coefficient of board size has a significant negative association with the likelihood of financial distress, which is consistent with the previous studies such as Mangena and Chamisa
(2008), Lajili and Zéghal (2010) and Shahwan (2015). Further, we observed an insignificant positive relationship between CEO duality and the likelihood of firm financial distress. Therefore, companies with CEO duality have more likelihood of financial distress in Pakistan. Similarly, a firm's size is a negative and highly significant association with the likelihood of firm financial distress in all models. The negative coefficient indicates that large companies have a low risk of default, due to their experiences and operational scope. Leverage is found significant positive association with the likelihood of financial distress, which suggests that debt financing enhance the probability of financial distress. Payout ratio, profit margin and firm growth have no significant effect on financial distress. The empirical results of the study indicate that board independence will reduce the likelihood of firm financial distress and improves firm's financial performance. Hence, the study suggests that the role of independent non-executive should be clearly defined in the Code of corporate governance, and SECP rigorously implements the independent non-executive directors' requirement in listed companies.

The present study focuses exclusively on the link between board structure and the likelihood of financial distress. Although, the empirical findings of the current study have important implications for laying good corporate governance practices across developed countries in general and emerging countries in particular. Our empirical findings advocated that good corporate governance practices lead to a lower risk of financial failure. Still, there are potential avenues for future research. Future studies are encouraged to use other financial distress models like market-based models or accounting-based models. Another fruitful extension of this study would be to investigate the relationship between corporate governance index (CG score) and likelihood of financial distress.

\section{References}

Aguilera, R. V., \& Cuervo-Cazurra, A. (2009). Codes of good governance. Corporate Governance: An International Review, 17(3), 376-387. https://doi.org/10.1111/j.14678683.2009.00737.x

Altman, E. I. (1968). Financial ratios, discriminant analysis and the prediction of corporate bankruptcy. The Journal of Finance, 23(4), 589-609. DOI: 10.2307/2978933

Baysinger, B. D., \& Butler, H. N. (1985). Corporate governance and the board of directors: Performance effects of changes in board composition. Journal of Law, Economics, \& Organization, 1(1), 101-124.

Berle, A., \& Means, G. (1932). The Modern Corporation and Private Property. New York, NY: McMillan.

Bethel, J. E., \& Liebeskind, J. (1993). The effects of ownership structure on corporate restructuring. Strategic Management Journal,14(S1),15-31.https://doi.org/10.1002/smj.4250140904 
Black, B. S., Love, I., \& Rachinsky, A. (2006). Corporate governance indices and firms' market values: Time series evidence from Russia. Emerging Markets Review, 7(4), 361-379. https://doi.org/10.1016/j.ememar.2006.09.004

Brédart, X. (2014). Financial distress and corporate governance: the impact of board configuration. International Business Research, 7(3), 72. https://doi.org/10.5539/ibr.v7n3p72

Cadbury, A. (1992). Report of the committee on the financial aspects of corporate governance (Vol. 1). London, UK: Gee J. Co Ltd.

Chaganti, R. S., Mahajan, V., \& Sharma, S. (1985). Corporate board size, composition and corporate failures in retailing industry. Journal of Management Studies, 22(4), 400-417. https://doi. org/10.1111/j.1467-6486.1985.tb00005.x

Chen, I.-J. (2014). Financial crisis and the dynamics of corporate governance: Evidence from Taiwan's listed firms. International Review of Economics \& Finance, 32, 3-28. https://doi. org/10.1016/j.iref.2014.01.004

Chen, Z., Cheung, Y.-L., Stouraitis, A., \& Wong, A. W. (2005). Ownership concentration, firm performance, and dividend policy in Hong Kong. Pacific-Basin Finance Journal, 13(4), 431-449. https://doi.org/10.1016/j.pacfin.2004.12.001

Committee, H. (1998). Final Report of the Committee on Corporate Governance. London, UK: Gee J. Co Ltd.

Crespí-Cladera, R., \& Pascual-Fuster, B. (2014). Does the independence of independent directors matter? Journal of Corporate Finance, 28, 116-134. DOI: 10.1016/j. jcorpfin.2013.12.009

Daily, C. M., \& Dalton, D. R. (1994). Bankruptcy and corporate governance: The impact of board composition and structure. Academy of Management Journal, 37(6), 1603-1617.

Donker, H., Santen, B., \& Zahir, S. (2009). Ownership structure and the likelihood of financial distress in the Netherlands. Applied Financial Economics, 19(21), 1687-1696. https://doi. org/10.1080/09603100802599647

Elloumi, F., \& Gueyie, J.-P. (2001). Financial distress and corporate governance: an empirical analysis. Corporate Governance: The International Journal of Business in Society, 1(1), 15-23. https://doi.org/10.1108/14720700110389548

Fama, E. F., \& Jensen, M. C. (1983). Agency problems and residual claims. The journal of law and Economics, 26(2), 327-349.

Fuzi, S. F. S., Halim, S. A. A., \& Julizaerma, M. (2016). Board independence and firm performance. Procedia Economics and Finance, 37, 460-465. https://doi.org/10.1016/S22125671(16)30152-6

Greenbury, R. (1995). Report of the Committee on Executive Remuneration. London, UK: Gee J. Co Ltd.

Hambrick, D. C., \& D'Aveni, R. A. (1992). Top team deterioration as part of the downward spiral of large corporate bankruptcies. Management Science, 38(10), 1445-1466. http://dx.doi. org/10.1287/mnsc.38.10.1445

He, L., Evans, E., \& Wright, S. (2007). Does better corporate governance result in lower earnings management? Keeping
Good Companies, 59(6), 330. https://doi.org/10.1007/s10551013-1700-8

Hermalin, B. E., \& Weisbach, M. S. (1988). The determinants of board composition. The RAND Journal of Economics, 589-606. DOI: $10.2307 / 2555459$

Higgs, D. (2003). Review of the role and effectiveness of nonexecutive directors. London, UK: Stationery Office.

Hodgson, A., Lhaopadchan, S., \& Buakes, S. (2011). How informative is the Thai corporate governance index? A financial approach. International Journal of Accounting \& Information Management, 9(1), 53-79. DOI:10.1108/18347641111105935

Hui, H., \& Jing-Jing, Z. (2008). Relationship between corporate governance and financial distress: An empirical study of distressed companies in China. International Journal of Management, 25(4), 654.

Jensen, M. C. (1993). The modern industrial revolution, exit, and the failure of internal control systems. the Journal of Finance, 48(3), 831-880. https://doi.org/10.1111/j.1540-6261.1993. tb04022.x

Khan, M. J., Hussain, D., \& Mehmood, W. (2016). Why do firms adopt enterprise risk management (ERM)? Empirical evidence from France. Management Decision, 54(8), 1886-1907. DOI:10.1108/MD-09-2015-0400

Lajili, K., \& Zéghal, D. (2010). Corporate governance and bankruptcy filing decisions. Journal of General Management, 35(4), 3-26. https://doi.org/10.1177\%2F030630701003500401

Lakshan, A., \& Wijekoon, W. (2012). Corporate governance and corporate failure. Procedia Economics and Finance, 2, 191198. https://doi.org/10.1016/S2212-5671(12)00079-2

Lee, T. S., \& Yeh, Y. H. (2004). Corporate governance and financial distress: Evidence from Taiwan. Corporate governance: An International Review, 12(3), 378-388. https://doi.org/10.1111/ j.1467-8683.2004.00379.X

Lin, F.-Y., Liang, D., \& Chu, W.-S. (2010). The role of nonfinancial features related to corporate governance in business crisis prediction. Journal of Marine Science and Technology, 18(4), 504-513.

Lipton, M., \& Lorsch, J. W. (1992). A modest proposal for improved corporate governance. The Business Lawyer, 48(1). 59-77.

Liu, Y., Miletkov, M. K., Wei, Z., \& Yang, T. (2015). Board independence and firm performance in China. Journal of Corporate Finance, 30, 223-244. DOI: 10.1016/j. jcorpfin.2014.12.004

Majeed, M. K., Jun, J. C., Zia-ur-Rehamn, M., Mohsin, M., \& Rafiq, M. Z. (2020). The Board Size and Board Composition Impact on Financial Performance: An evidence from the Pakistani and Chinese Listed Banking Sector. Journal of Asian Finance, Economics, 7(4), 81-95. https://doi.org/10.13106/jafeb.2020. vol7.no4.81

Mallette, P., \& Fowler, K. L. (1992). Effects of board composition and stock ownership on the adoption of "poison pills". Academy of Management Journal, 35(5), 1010-1035. https:// doi.org/10.5465/256538 
Mangena, M., \& Chamisa, E. (2008). Corporate governance and incidences of listing suspension by the JSE Securities Exchange of South Africa: An empirical analysis. The International Journal of Accounting, 43(1), 28-44. https://doi.org/10.1016/j. intacc.2008.01.002

Manzaneque, M., Merino, E., \& Priego, A. M. (2016). The role of institutional shareholders as owners and directors and the financial distress likelihood. Evidence from a concentrated ownership context. European Management Journal, 34(4), 439-451. https://doi.org/10.1016/j.emj.2016.01.007

Manzaneque, M., Priego, A. M., \& Merino, E. (2016). Corporate governance effect on financial distress likelih+ood: Evidence from Spain. Revista de Contabilidad, 19(1), 111-121. https:// doi.org/10.1016/j.rcsar.2015.04.001

Miglani, S., Ahmed, K., \& Henry, D. (2015). Voluntary corporate governance structure and financial distress: evidence from Australia. Journal of Contemporary Accounting \& Economics, 11(1), 18-30. https://doi.org/10.1016/j.jcae.2014.12.005

Nahar Abdullah, S. (2006). Board structure and ownership in Malaysia: The case of distressed listed companies. Corporate Governance: The International Journal of Business in Society, 6(5), 582-594. DOI 10.1108/14720700610706072

Nakano, M., \& Nguyen, P. (2012). Board Size and Corporate Risk-Taking: Further Evidence from Japan. Corporate Governance: An International Review, 20(4), 369-387. https:// doi.org/10.1111/j.1467-8683.2012.00924.x

Nanka-Bruce, D. (2009). Corporate governance and multidimensional performance. Barcelona, Spain: Universitat Autònoma de Barcelona.

Pearce, J. A., \& Zahra, S. A. (1992). Board composition from a strategic contingency perspective. Journal of Management Studies, 29(4), 411-438. https://doi. org/10.1111/j.1467-6486.1992.tb00672.x

Pfeffer, J. (1972). Size and composition of corporate boards of directors: The organization and its environment. Administrative Science Quarterly, 218-228. http://dx.doi.org/10.2307/2393956

Pound, J. (1992). On the motives for choosing a corporate governance structure: A study of corporate reaction to the Pennsylvania takeover law. Journal of Law, Economics and Organizationl, 8, 656.

Rahman, M. M., \& Saima, F. N. (2018). Efficiency of board composition on firm performance: Empirical evidence from listed manufacturing firms of Bangladesh. Journal of Asian Finance, Economics and Business, 5(2), 53-61. https://doi. org/10.13106/jafeb.2018.vol5.no2.53

Salancik, G. R., \& Pfeffer, J. (1980). Effects of ownership and performance on executive tenure in US corporations. Academy of Management Journal, 23(4), 653-664. https://doi. org/10.5465/255554
Shahwan, T. M. (2015). The effects of corporate governance on financial performance and financial distress: evidence from Egypt. Corporate Governance, 15(5), 641-662. https://doi. org/10.1108/CG-11-2014-0140

Sheikh, M. F., Bhutta, A. I., \& Sultan, J. (2019). CEO Compensation and Unobserved Firm Performance in Pakistan. Journal of Asian Finance, Economics and Business, 6(3), 305-313. https:// doi.org/10.13106/jafeb.2019.vol6.no3.305

Tahir, H., Rahman, M., \& Masri, R. (2020). Do Board Traits Influence Firms' Dividend Payout Policy? Evidence from Malaysia. Journal of Asian Finance, Economics and Business, 7(3), 87-99. https://doi.org/10.13106/jafeb.2020.vol7.no3.87

Tahir, S. H., Sadique, M. A. B., Nausheen, S., Rehman, F., \& Ullah, M. R. (2020). Mediating Role of Liquidity Policy on the Corporate Governance-Performance Link: Evidence from Pakistan. Journal of Asian Finance, Economics and Business, 7(8), 15-23. https://doi.org/10.13106/jafeb.2020.vol7.no8.015

Wang, Z.-J., \& Deng, X.-L. (2006). Corporate governance and financial distress: Evidence from Chinese listed companies. Chinese Economy, 39(5), 5-27. https://doi.org/10.2753/ CES1097-1475390501

Yermack, D. (1996). Higher market valuation of companies with a small board of directors. Journal of Financial Economics, 40(2), 185-211. https://doi.org/10.1016/0304-405X(95)00844-5

\section{Endnotes}

${ }^{1} \mathrm{http}: / / \mathrm{www}$.ecgi.global/code/code-corporate-governanceinsurers-2016- The code of corporate governance 2013, issued by SECP clearly mentioned that "the Board shall consist of executive and non-executive directors, including independent directors and those representing minority interests with the requisite range of skills, competence, knowledge, experience and approach so that the Board as a group includes core competencies and diversity considered relevant in the context of the Public-Sector Company's operations" (CG Rule. 2013, p.3).

${ }^{2}$ Manufacturing sector is the third largest sector contributing $13.5 \%$ to Gross Domestic Product (GDP) of Pakistan and 14\% of the total employment

${ }^{3} \mathrm{We}$ used the Z-score to predict financial distress. The Z-score formula was developed by Altman (1968). We used the Altman Z-score as a proxy for financial distress. We construct the Altman Z-score using firm earnings before taxes, sales, and total assets. The Altman Z-score is given as: $\mathrm{Z}=1.2 \mathrm{X} 1+1.4 \mathrm{X} 2$ $+3.3 \mathrm{X} 3+0.6 \mathrm{X} 4+1.0 \mathrm{X} 5$. Where $\mathrm{X} 1=$ net working capital $/$ total assets, $\mathrm{X} 2=$ retained earnings /total assets, $\mathrm{X} 3=$ =arnings before interests and taxes (EBIT)/total assets, $\mathrm{X} 4=$ market value of equity and preferred stock/book value of debt, and X5 =sales revenue/total assets (Altman, 1968)." 